\title{
Greenhouse Evaluation of Pinewood Biochar Effects on Nutrient Status and Physiological Performance in Muscadine Grape (Vitis rotundifolia $\mathbf{L}$.)
}

\author{
Yuru Chang \\ Horticultural Sciences Department, University of Florida, Gainesville, FL \\ 32611
}

Lorenzo Rossi

Horticultural Sciences Department, University of Florida, Institute of Food and Agricultural Sciences, Indian River Research and Education Center, Ft. Pierce, FL 34945

\section{Lincoln Zotarelli \\ Horticultural Sciences Department, University of Florida, Gainesville, FL 32611}

\section{Bin Gao}

Agricultural and Biological Engineering Department, University of Florida, Gainesville, FL 32611

\section{Ali Sarkhosh \\ Horticultural Sciences Department, University of Florida, Gainesville, FL 32611}

Additional index words. muscadine grape growth, nutrient status, pinewood-based biochar, soil physical properties, viticulture

\begin{abstract}
Muscadine grape is a perennial crop that is highly responsive to local environmental factors and viticulture practices. Biochar is a promising soil amendment used to improve soil water and nutrient retention and promote plant growth. The present study aimed to assess the effects of different pinewood biochar rates on nutrient status and vegetative parameters of muscadine grape cv. Alachua grown on a nutrient-poor sandy soil, Ultisols $(97.2 \%$ sand, $2.4 \%$ silt, and $0.4 \%$ clay), and mixed with five different rates $(0 \%, 5 \%, 10 \%, 15 \%$, and $20 \%)$ of biochar based on weight. Variations in soil moisture, temperature, and leaf greenness value [soil plant analysis development (SPAD) reading], net photosynthesis rate, and plant root and shoot dry weights were measured. In addition, the nutrient status of the soil, plant root, and shoot were determined. The results indicated that the higher rate of biochar could significantly $(P<0.05)$ improve soil moisture. Biochar can also decrease soil temperature, although there were no significant differences among treatments. Regarding the nutrient status, the biochar amendment increased the nutrient content of phosphorus $(\mathrm{P})$, potassium $(\mathrm{K})$, magnesium $(\mathrm{Mg})$, and calcium $(\mathrm{Ca})$, as well as the soil organic matter content and cation exchange capacity. Higher nutrient contents in soil lead to increased $\mathrm{P}$ and $\mathrm{Mg}$ in both aboveground and belowground muscadine plant tissues and decreased nitrogen $(\mathrm{N})$, iron $(\mathrm{Fe})$, and copper $(\mathrm{Cu})$ in the root part. There were no significant differences observed in SPAD values, net photosynthesis, or dry weights of the root and shoot. This study demonstrates that the addition of biochar may enhance the soil water and nutrient status as well as improve plant $P$ and Mg uptake; however, it showed no significant differences in the physiological performance of muscadine grape plants.
\end{abstract}

The Muscadine grape (Vitis rotundifolia L., Vitaceae) is the predominant grape cultivar commonly grown in the southeastern United States, with current markets existing for juice, wine, and fresh fruit (Duarte Alonso and O’Neill, 2012). Most Florida vineyard soils are characterized by poor soil fertility; the soil is highly susceptible to erosion (Collins, 2017; Gillette and Walker, 1977; Marchi et al., 2016) and has low organic matter contents (Brown et al., 2018), nutrient and water retention (Githinji, 2014), and cation exchange capacity (CEC) (Marx et al., 1996; Reichert et al., 2016). Rapid drainage leads to nutrient leaching through sand-based root zones (Bigelow et al., 2001; Mohamed et al., 2016; Petri and Petrovic, 2001). Therefore, plant growth is strongly limited by root growth and fewer available nutrients in sandy soil (Bruun et al., 2014). Undesirable soil conditions influence the annual nutrient consumption and total nutrient content of grapevine leaves as well as fruit quality.

Biochar is a pyrolysis product of organic materials, which means thermal degradation under anaerobic and hypoxic conditions (Kan et al., 2016; Lehmann and Joseph, 2015). It is also called black gold because it can improve soil fertility and increase agricultural crop production. There are three main reasons for improving soil fertility: increasing soil $\mathrm{pH}$ (Aamer et al., 2020; Rees et al., 2014; Weber and Quicker, 2018); improving nutrient retention through higher CEC (Gondek et al., 2019; Laghari et al., 2015; Nikravesh et al., 2019; Wang et al., 2019); and optimizing the physical properties, such as surface area and pore structure (Batista et al., 2018; Lehmann et al., 2011; Obour et al., 2019). All these directly affect the microbial biomass (Dempster et al., 2012; Silva et al., 2020), microbial community composition and abundance (Kaurin et al., 2018; Palansooriya et al., 2019; Zhu et al., 2017), and enzyme activities (Bailey et al., 2011; Irfan et al., 2019). Therefore, crop growth and production will be indirectly affected because of more fungi (Duan et al., 2019; Ohsowski et al., 2018; Schwartz et al., 2006) and rhizosphere bacteria (Aggangan et al., 2019; Compant et al., 2010)

Soil amendment with biochar has been recommended as a new way to improve soil properties, including the water-holding capacity (Kammann et al., 2012; Marshall et al., 2019), water infiltration (Ippolito et al., 2012; Novak et al., 2016), soil water availability, nutrient retention (Clough et al., 2013; Sorrenti et al., 2016; Ventura et al., 2013), hydraulic conductivity (Buss et al., 2012; Liu et al., 2016), and soil aeration (Case et al., 2012; Obia et al., 2018). Significant increases in soil fertility, plant growth, and yield have been reported when biochar was applied to the soil surface in tropical and subtropical regions (Agegnehu et al., 2016a; Atkinson et al., 2010; Jeffery et al., 2017; Major et al., 2010). However, no studies have considered the effects of biochar on the intrinsic properties of the sandy soil in Florida vineyards.

Biochar can provide essential elements (Glaser et al., 2002) and promote nutrient retention in soil (Berek et al., 2018; Buss et al., 2018; Laird, 2008). Research of common beans showed that biochar can improve $\mathrm{K}, \mathrm{Ca}, \mathrm{P}$, boron (B), and molybdenum (Mo) availability. However, under the high application rate of biochar, the available $\mathrm{N}$ and common beans biomass (although not yield) were decreased (Rondon et al., 2007). Moreover, research of other plants, such as grape, wheat, maize, rice, peanut, and tomato, indicated that, with an appropriate rate of biochar, the plant yield will be increased (Agegnehu et al., 2015, 2016b; Akhtar et al., 2014; Alburquerque et al., 2013; Ferreira et al., 2017; Liu et al., 2016; Vaccari et al., 2011; Zhang et al., 2012a, 2012b). The response of soil fertility and plant productivity to biochar application has been highly variable. Fertility responses can vary with the 
nature of the biochar feedstock, total application rate, crop species, soil type, and other soil inputs, such as compost, as well as a combination of these factors (Gao et al., 2016).

No studies have reported the influences of pinewood biochar application on muscadine growth. This study aimed to examine whether pinewood biochar would: 1) improve soil nutrient and water retention; 2) increase nutrient uptake by muscadine grapes; and 3) promote muscadine grape growth.

\section{Materials and Methods}

Experimental site and materials. 'Alachua', a planted muscadine grape cultivar, was used for this experiment. One-month-old tissue-cultured vines were purchased from AgriStarts propagating nursery (Lakeland, FL). The activated biochar, produced by pyrolysis of southern yellow pine at $400{ }^{\circ} \mathrm{C}$, was produced by Mirimichi Green Express, LLC (Castle Hayne, NC). The particle size is generally uniformly distributed between 0.6 and $10 \mathrm{~mm}$. Table 1 shows the characteristics of the experimental soil and the pinewood biochar. The organic matter concentration of biochar was $616 \mathrm{~g} \cdot \mathrm{kg}^{-1}$, which is 33.7-times that of sandy soil $\left(<18.3 \mathrm{~g} \cdot \mathrm{kg}^{-1}\right)$. In addition, the CEC value of pinewood biochar is 20.13 meq/100 g, which is 7.1-times higher than that of sandy soil $(2.83 \mathrm{meq} / 100 \mathrm{~g})$. The surface morphology of the biochar sample was then studied using a FEI Nova 430 scanning electron microscope (SEM; FEI Company, Hillsboro, OR). Pinewood is one of the cheapest biochar feedstocks, and it is the most viable and suitable for growers; therefore, it was used during the present study.

Experimental design. This study was performed in a greenhouse at the University of Florida, Plant Science Research and Education Unit (PSREU; lat. $29.40^{\circ} \mathrm{N}$, long. $82.17^{\circ} \mathrm{W}$, altitude $21 \mathrm{~m}$ ) in Citra, FL. To simulate the natural growth environment, the surface soil was taken from an assigned organic area (soil was free from herbicides and pesticide residuals) at a depth of $30 \mathrm{~cm}$ at the PSREU. This area is characterized by sandy soil $\left(972 \mathrm{~g} \cdot \mathrm{kg}^{-1}\right.$ of sand, $2.4 \mathrm{~g} \cdot \mathrm{kg}^{-1}$ of silt, and $4 \% \mathrm{~g} \cdot \mathrm{kg}^{-1}$ of clay). This is a typical soil type in the southeastern United States, especially Florida. The limited water-holding

Received for publication 5 Oct. 2020. Accepted for publication 14 Dec. 2020.

Published online 14 January 2021.

The Florida Department of Agriculture and Consumer Services are acknowledged for financial support of this study. We thank Dustin Huff and stone fruit laboratories in the Horticultural Sciences Department at the University of Florida for their assistance during laboratory and greenhouse experiments.

A.S. is the corresponding author. E-mail: sarkhosha @ ufl.edu.

This is an open access article distributed under the $\mathrm{CC}$ BY-NC-ND license (https://creativecommons.org/ licenses/by-nc-nd/4.0/).

Table 1. Physiochemical properties of the tested soil and pinewood biochar in this study.

\begin{tabular}{lcc}
\hline Characteristics & Sandy soil & Pinewood biochar \\
\hline Active carbon (ppm) & 182 & 526 \\
Organic matter (\%) & 1.83 & 61.6 \\
Total N (kg/ha) & 1.04 & 16.27 \\
Total P (kg/ha) & 47.08 & 558.18 \\
Total K (kg/ha) & 19.05 & 1276.65 \\
pH & 5.7 & 6.1 \\
CEC (meq/100 g) & 2.83 & 20.13 \\
Clay (\%) & 0.4 & 0.8 \\
Silt (\%) & 2.4 & 20 \\
Sand $(\%)$ & 97.2 & 79.2 \\
\hline
\end{tabular}

$\overline{\mathrm{CEC}}=$ cation exchange capacity.

capacity of sand leads to increased leaching of nutrients ( $\mathrm{Yu}$ et al., 2013). Biochar was applied and incorporated in the soil $3 \mathrm{~d}$ before planting in different proportions of $5 \%, 10 \%$, $15 \%$, and $20 \%$ on a dry weight basis. A control treatment comprising soil with unenriched biochar was used to compare the results with those of the other treatments incorporating different biochar rates. Then, the volume of the total potting media across biochar rate gradient was adjusted to a constant. Different percentages of sandy soil and biochar were thoroughly and gently mixed by hand to avoid damaging the biochar particle structure. This experiment had a randomized complete block design with five treatments and six blocks. Each replication plot consisted of two plants.

To monitor the effects of biochar on muscadine seedlings growth, 60 tissuecultured muscadine plants were planted individually in 1.5-gal pots filled with the five different proportions of biochar/soil mixtures. Then, the pots were used for a short-term study lasting 16 weeks. Two data loggers were installed in the greenhouse to record the temperature and humidity values every 15 min during the experiment.

Environmental conditions. The temperature inside the greenhouse was set between 18 and $26^{\circ} \mathrm{C}$. Fertilizer was applied weekly through the irrigation system with standard $\mathrm{N}-\mathrm{P}-\mathrm{K}(10-10-10)$ plus micronutrients. One dripper with a flow rate of $40 \mathrm{~mL} \cdot \mathrm{min}^{-1}$ was installed in each pot. The irrigation system worked three times per day for $2 \mathrm{~min}$ at 8:00 $\mathrm{AM}, 2 \mathrm{~min}$ at 2:00 $\mathrm{PM}$, and $2 \mathrm{~min}$ at 8:00 $\mathrm{PM}$, resulting in a total of $240 \mathrm{~mL} \cdot \mathrm{d}^{-1}$ of water received. The trellis system was installed to support grape growth 2 weeks after transplanting.

Soil characteristic measurements. The soil moisture was measured biweekly with a double-probe soil moisture meter (HydroSense II Handheld Soil Moisture Sensor; Campbell Scientific, Logan, UT). The soil temperature was measured monthly by a digital laboratory thermometer with a stainless-steel probe (DT301LAB stem thermometer; General Tools, New York, NY). Soil moisture and temperature were both measured at a depth of $15 \mathrm{~cm}$, which is the main root zone. The measured soil moisture content should be based on the gravimetric water content percentage ( $\mathrm{GWC} \%$ ) because the percentages of biochar in the mixtures were considered weight-based. However, the data from the soil moisture meter were recorded as the volumetric water content percentage (VWC\%). The conversion equation was performed using the following formula (ElDine and Hosny, 2000):

$$
V W C \%=G W C \% \times\left(\frac{B D}{\rho_{w}}\right),
$$

$B D$ refers to the bulk density of soil and $\rho_{w}$ refers to water density equal to $1 \mathrm{~g} \cdot \mathrm{cm}^{-3}$. In this case, the following formula was used:

$$
G W C \%=\frac{V W C \%}{B D} \text {. }
$$

Nutrient content analysis. At the end of the experiment, the nutrient contents, including $\mathrm{N}, \mathrm{P}, \mathrm{K}, \mathrm{Ca}, \mathrm{Mg}$, sulfur (S), zinc ( $\mathrm{Zn}), \mathrm{Fe}$, $\mathrm{Cu}, \mathrm{Mn}$, and $\mathrm{B}$, as well as the organic matter $(\mathrm{OM})$ in soil, root, and shoot tissues were analyzed using an ICAP-Open vessel wet digestion system (Digi Block 3000; Waters Agricultural Laboratories Inc., Camilla, GA; https://watersag.com/services/). The nutrient measurements followed the protocol described by Isaac and Johnson (1985).

The base saturation percentage (BS\%) represents the CEC value occupied by the basic cations, such as $\mathrm{Ca}^{2+}, \mathrm{Mg}^{2+}$, and $\mathrm{K}^{+}$. The base saturation percentage was expressed as follows:

$$
\% B S=\frac{C a^{2+}+M g^{2+}+K^{+}}{C E C} \times 100 \% .
$$

Muscadine grape physiological performance. The chlorophyll values of the first four mature and healthy leaves from the growing point of each plant were recorded 35 and $54 \mathrm{~d}$ after transplanting with a portable SPAD 502 chlorophyll fluorimeter (Konica Minolta, Tokyo, Japan). The net photosynthetic rate was determined by using a LI-COR 6400 XT Portable Photosynthesis System (LI-COR, Lincoln, NE) 16 weeks after transplanting and before harvesting. LI-COR readings were obtained between 11:00 AM and 2:00 PM. After a destructive harvest, all the plants in each pot were collected and separated into roots and shoots. Dry weights of roots and shoots were determined using a digital scale with a precision of $1 \mathrm{~g}$ after $72 \mathrm{~h}$ at $55^{\circ} \mathrm{C}$ in a drying oven.

Statistical analysis. All collected data were analyzed using the GLIMMIX procedure with SAS statistical software (ANOVA 
SAS 9.1; SAS Institute, Cary, NC). The mean analysis was performed with the TukeyKramer test at $P \leq 0.05$.

\section{Results and Discussion}

SEM characterization and soil physical properties. The SEM micrographs of the pinewood biochar particles at magnifications of $\times 100, \times 500$, and $\times 1000$ are shown in Fig. 1. These SEM images represent the porous structure of the biochar samples used. Also, the SEM images show that raw biochar had smooth particles with a polygonal shape. The large channel-like structures proliferate the surface of biochar, showing at least par- tial retention of the morphology of the initial input biomass.

During the first two measurements, the soil temperature at a depth of $15 \mathrm{~cm}$ decreased with the increased biochar rate. The third measurement showed a downward trend; however, no statistically significant difference was found between groups
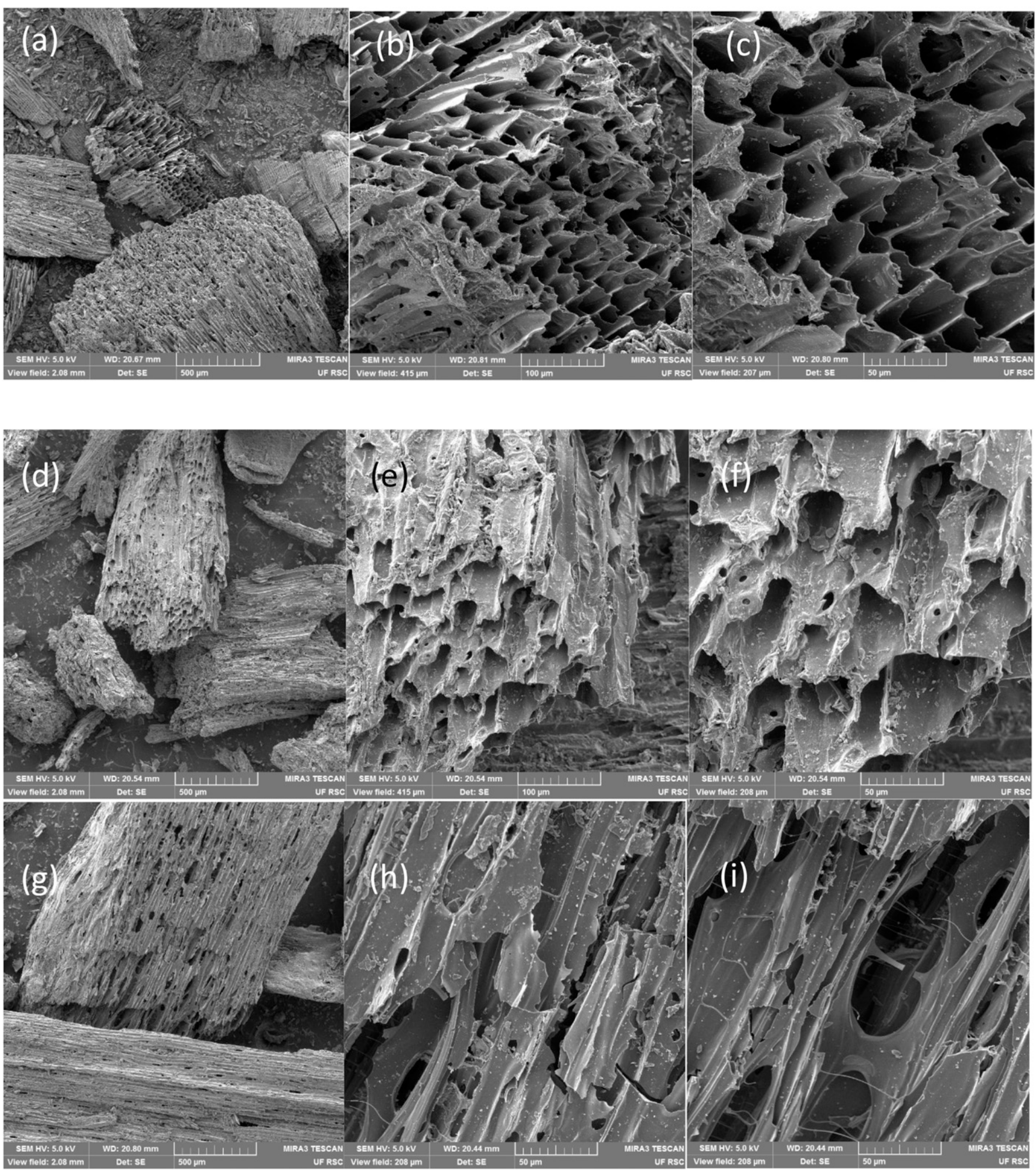

Fig. 1. Scanning electron microscopy (SEM) images (bar, $50 \mu \mathrm{m} ; \times 1000$ magnification) of the pinewood biochar particles at magnifications of $\times 100$ (A, D, J), $\times 500(\mathbf{B}, \mathbf{E}, \mathbf{H})$, and $\times 1000(\mathbf{C}, \mathbf{F}, \mathbf{I})$. 
(a)
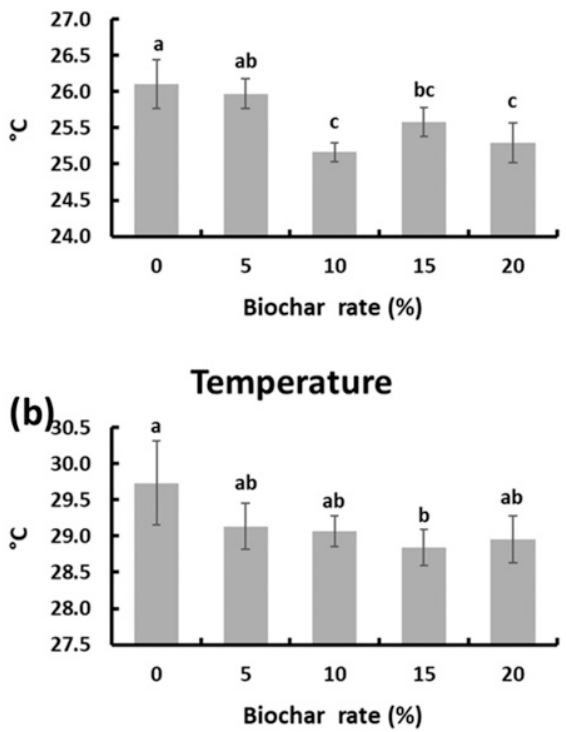

Temperature

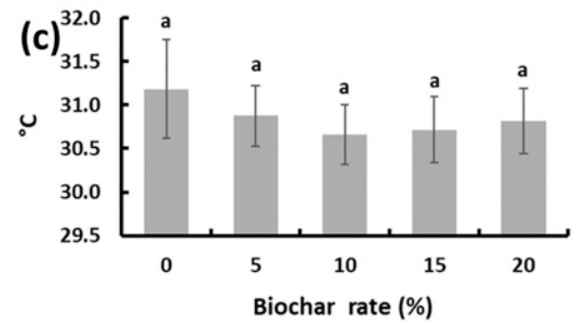

Fig. 2. Soil temperatures measured in May, June, and July, respectively. (A) Measured on transplanting day. (B) Measured $33 \mathrm{~d}$ after transplanting. (C) Measured $52 \mathrm{~d}$ after transplanting. Bars with the same letters indicate that the means are not significantly $(P \leq 0.05)$ different according to the Tukey-Kramer test. Error bars show the SE $(\mathrm{n}=12)$.

(Fig. 2). According to Zhang et al. (2013), the thermal conductivity of the soil significantly decreased by $3.48 \%$ and $7.49 \%$ with 4.5 and $9 \mathrm{Mg} \cdot \mathrm{ha}^{-1} \cdot \mathrm{year}^{-1}$, respectively, following the application of biochar. This was also consistent with the decrease in soil bulk density. The same author reported that biochar treatment might regulate the extreme soil temperature, thus reducing the temperature when the soil temperature is high and increasing it when the soil temperature is low. The adjustment capabilities of the daily average temperature and diurnal range of the soil were mostly within \pm 0.4 and $\pm 0.8{ }^{\circ} \mathrm{C}$, respectively. Zhang et al. (2013) assumed that the regulation of soil temperatures by biochar might be explained by the combined action of changes in soil thermal conductivity and reflectance.

Figure 3 illustrates the soil moisture content in terms of the gravimetric water content percentage. Apparently, biochar significantly improved the soil moisture content. The first soil moisture measurement was performed $35 \mathrm{~d}$ after transplanting. The second measurement was performed $54 \mathrm{~d}$ after trans- (a) Moisture

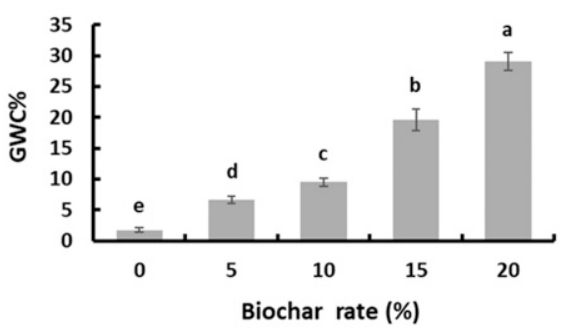

(b)

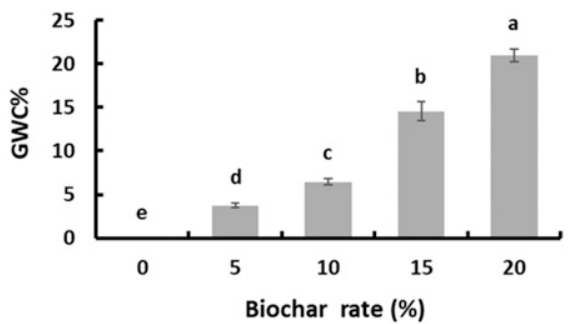

Fig. 3. Soil moisture in gravimetric water content $(\mathrm{GWC} \%)$ in the bag and pot in June and July. (A) Measurements of the plants in a pot $33 \mathrm{~d}$ after transplanting. (B) Measurements of the plants in a pot $54 \mathrm{~d}$ after transplanting. Bars with the same letters indicate that the means are not significantly $(P \leq 0.05)$ different according to the Tukey-Kramer test. Error bars show the SE $(n=12)$.

planting, after the soil was treated with drought stress by stopping irrigation for 24 $\mathrm{h}$. The first measurement indicated that the moisture of the amended soil with the highest biochar rate $(20 \%)$ was 17 -times higher than that of the control group. The second measurement indicated that the average soil moisture rates were $0.03 \%$ and $20.9 \%$ in the control group and $20 \%$ in the biocharamended group, respectively. In this case, a moisture rate of $20 \%$ in the biochar-amended soil is 847-times higher than that of pure sandy soil during the bag experiment and pot experiment. Therefore, it has been concluded that biochar can significantly $(P<0.05)$ increase soil moisture, especially under drought stress conditions.

The application of biochar can improve negative effects of drought and salt stress on plants. According to a recent study by Ali et al. (2017), the application of biochar improved the growth, biomass, and yield of the plants, and it enhanced photosynthesis, nutrient absorption, and gas exchange characteristics of treated plants exposed to drought salt stress. In addition, it indicated that biochar improved the soil water-holding capacity and physical and biological properties, as well as decreased the absorption of $\mathrm{Na}^{+}$and increased the absorption of $\mathrm{K}^{+}$by plants under salt stress (Ali et al., 2017). The results of a biochar experiment performed in a nonirrigated vineyard in central Italy also indicated that an increase in grape productivity was inversely proportional to precipitation during the vegetative period, thus confirming the vital role of biochar in managing plant water availability (Genesio et al., 2015). Similarly, a biochar experiment conducted in southwest Spain for sunflower (one of the most important nonirrigated crops in Southern Europe) showed better growth of amended plants during the drought period. A higher reduction of stomatal conductance, indicating an improvement in water use efficiency, is the main reason for better crop performance following biochar treatment (Paneque et al., 2016).

Nutrient content analysis. The contents of $\mathrm{P}, \mathrm{K}, \mathrm{Mg}, \mathrm{Ca}, \mathrm{BS}-\mathrm{K}$ (the value of $\mathrm{CEC}$ occupied by $\mathrm{K}^{+}$), BS-Mg (the value of CEC occupied by $\mathrm{Mg}^{2+}$ ), and organic matter significantly increased with a higher rate of biochar amendment, whereas the contents of BS-H (the value of CEC occupied by $\mathrm{H}^{+}$) decreased significantly (Table 2 ). There was no difference in the BS-K content, which was confirmed by another biochar experiment using sugarcane seedlings (Yang et al., 2015). These basic cations are different from acid cations $\mathrm{H}^{+}$and $\mathrm{Al}^{3+}$. Therefore, soils with a high percentage of base saturation generally have more fertility because soils with a high percentage of base saturation show lower BS-H and higher $\mathrm{pH}$ (Gaspar and Laboski, 2016). Therefore, they have a greater buffering effect on acid cations from plant roots and soil acidification. Furthermore, they contain greater amounts of essential plant nutrient cations $\mathrm{Ca}^{2+}$ and $\mathrm{Mg}^{2+}$ for plant use.

The concentrations of nutrients in root tissues are presented in Table 3 . The contents of $\mathrm{P}$ and $\mathrm{Mg}$ increased $4 \%$ and $20 \%$, respectively, with the $20 \%$ biochar rate compared with the control group. In contrast to the trend observed for $\mathrm{P}$ and $\mathrm{Mg}, \mathrm{N}$ significantly decreased following the $20 \%$ biochar amendment. However, $\mathrm{Fe}$ and $\mathrm{Cu}$ significantly decreased on soil amendment with $10 \%$ biochar. The $\mathrm{K}, \mathrm{Ca}, \mathrm{S}, \mathrm{B}, \mathrm{Zn}$, and $\mathrm{Mn}$ contents were not significantly affected by the treatments. The concentrations of nutrients in shoot tissues are presented in Tables 4. Biochar treatment had no significant effects on $\mathrm{N}, \mathrm{K}, \mathrm{S}, \mathrm{B}, \mathrm{Zn}, \mathrm{Ca}, \mathrm{Mn}, \mathrm{Fe}$, and $\mathrm{Cu}$ contents; however, it did have an effect on the $\mathrm{P}$ and $\mathrm{Mg}$ contents in shoot tissues.

Muscadine roots responded to soil improvement because biochar can serve as a nutrient source through the addition of soluble $\mathrm{P}$ and biochar $\mathrm{N}$ retention and by changing the soil nutrient content (Prendergast-Miller et al., 2014). Although the soil nutrients were significantly increased after biochar amendment, only a few mineral nutrients, such as $\mathrm{P}$ and $\mathrm{Mg}$, increased in plant tissues. Decreases in $\mathrm{Fe}$ and $\mathrm{Cu}$ may have been attributable to an increase in soil $\mathrm{pH}$ caused by the liming effect of biochar. A higher soil $\mathrm{pH}$ was negatively correlated with the availability of $\mathrm{Fe}$ and $\mathrm{Cu}$, leading to reductions in their uptake by the plant (Bravo et al., 2017). Decreased N can be explained by the porous structure of biochar because its high surface area and CEC determine the higher 
Table 2. Nutrient content in postharvest soil as influenced by the biochar treatments.

\begin{tabular}{|c|c|c|c|c|c|}
\hline Biochar rate $\%$ & 0 & 5 & 10 & 15 & 20 \\
\hline $\bar{P}(\%)$ & $125.83 \mathrm{c}^{\mathrm{z}}$ & $178.00 \mathrm{~b}$ & $166.00 \mathrm{~b}$ & $224.50 \mathrm{a}$ & $222.17 \mathrm{a}$ \\
\hline $\mathrm{Mg}(\%)$ & $108.67 \mathrm{c}$ & $176.50 \mathrm{~b}$ & $200.33 \mathrm{~b}$ & $272.17 \mathrm{a}$ & $301.50 \mathrm{a}$ \\
\hline $\mathrm{Ca}(\%)$ & $707.33 \mathrm{c}$ & $1487.00 \mathrm{~b}$ & $1505.33 \mathrm{~b}$ & $2116.00 \mathrm{a}$ & $2219.17 \mathrm{a}$ \\
\hline $\mathrm{pHb}^{\mathrm{y}}$ & $7.79 \mathrm{a}$ & $7.78 \mathrm{ab}$ & $7.74 \mathrm{bc}$ & $7.70 \mathrm{~cd}$ & $7.68 \mathrm{~d}$ \\
\hline CEC (\%) & $4.22 \mathrm{c}$ & $6.57 \mathrm{~b}$ & $7.00 \mathrm{~b}$ & $9.25 \mathrm{a}$ & $9.87 \mathrm{a}$ \\
\hline BS-K (\%) & $7.32 \mathrm{a}$ & $4.88 \mathrm{a}$ & $4.60 \mathrm{a}$ & $4.83 \mathrm{a}$ & $4.88 \mathrm{a}$ \\
\hline BS-H (\%) & $39.95 \mathrm{a}$ & $27.23 \mathrm{~b}$ & $29.63 \mathrm{~b}$ & $25.93 \mathrm{~b}$ & $26.32 \mathrm{~b}$ \\
\hline $\mathrm{OM}^{\mathrm{y}}(\%)$ & $0.41 \mathrm{c}$ & $0.68 \mathrm{~b}$ & $0.86 \mathrm{~b}$ & $1.20 \mathrm{a}$ & $1.37 \mathrm{a}$ \\
\hline
\end{tabular}

${ }^{\mathrm{z}}$ The means followed by the same letters are not significantly different $(P \leq 0.05)$ according to the Tukey-Kramer test.

${ }_{\mathrm{p}}^{\mathrm{pHw}} \mathrm{pHb}$, BS, and OM refer to $\mathrm{pH}$ measured from dissolving soil in the water, $\mathrm{pH}$ measured from dissolving soil in the buffer solution, base saturation, and organic matter, respectively.

Table 3. Nutrient content in root tissues as influenced by the biochar treatments.

\begin{tabular}{|c|c|c|c|c|c|}
\hline Biochar rate $\%$ & 0 & 5 & 10 & 15 & 20 \\
\hline $\bar{N}(\%)$ & $1.58 \mathrm{a}^{z}$ & $1.62 \mathrm{a}$ & $1.57 \mathrm{ab}$ & $1.47 \mathrm{ab}$ & $1.39 \mathrm{~b}$ \\
\hline $\mathrm{K}(\%)$ & $0.72 \mathrm{a}$ & $0.70 \mathrm{a}$ & $0.72 \mathrm{a}$ & $0.74 \mathrm{a}$ & $0.73 \mathrm{a}$ \\
\hline $\mathrm{Mg}(\%)$ & $0.25 \mathrm{c}$ & $0.26 \mathrm{bc}$ & $0.28 \mathrm{abc}$ & $0.29 \mathrm{ab}$ & $0.30 \mathrm{a}$ \\
\hline S (\%) & $0.15 \mathrm{a}$ & $0.15 \mathrm{a}$ & $0.15 \mathrm{a}$ & $0.15 \mathrm{a}$ & $0.15 \mathrm{a}$ \\
\hline B (ppm) & $16.42 \mathrm{ab}$ & $17.25 \mathrm{ab}$ & $16.17 \mathrm{~b}$ & $18.50 \mathrm{~b}$ & $19.33 \mathrm{a}$ \\
\hline $\mathrm{Zn}(\mathrm{ppm})$ & $65.67 \mathrm{~b}$ & $66.67 \mathrm{ab}$ & $67.33 \mathrm{ab}$ & $77.08 \mathrm{a}$ & $75.75 \mathrm{ab}$ \\
\hline $\mathrm{Cu}(\mathrm{ppm})$ & $17.00 \mathrm{a}$ & $14.50 \mathrm{ab}$ & $12.92 \mathrm{~b}$ & $12.67 \mathrm{~b}$ & $12.00 \mathrm{~b}$ \\
\hline
\end{tabular}

${ }^{\mathrm{z}}$ The means followed by the same letters are not significantly different $(P \leq 0.05)$ according to the Tukey-Kramer test.

Table 4. Nutrient content in shoot tissues as influenced by biochar treatments.

\begin{tabular}{|c|c|c|c|c|c|}
\hline Biochar rate \% & 0 & 5 & 10 & 15 & 20 \\
\hline $\bar{N}(\%)$ & $2.56 \mathrm{a}^{z}$ & $2.53 \mathrm{a}$ & $2.53 \mathrm{a}$ & $2.49 \mathrm{a}$ & $2.45 \mathrm{a}$ \\
\hline $\mathrm{K}(\%)$ & $1.10 \mathrm{a}$ & $1.13 \mathrm{a}$ & $1.07 \mathrm{a}$ & $1.06 \mathrm{a}$ & $1.09 \mathrm{a}$ \\
\hline $\mathrm{Mg}(\%)$ & $0.22 \mathrm{~b}$ & $0.22 \mathrm{~b}$ & $0.23 \mathrm{ab}$ & $0.24 \mathrm{ab}$ & $0.26 \mathrm{a}$ \\
\hline S (\%) & $0.31 \mathrm{a}$ & $0.29 \mathrm{a}$ & $0.29 \mathrm{a}$ & $0.30 \mathrm{a}$ & $0.29 \mathrm{a}$ \\
\hline B (ppm) & $22.42 \mathrm{a}$ & $22.00 \mathrm{a}$ & $23.08 \mathrm{a}$ & $22.67 \mathrm{a}$ & $24.00 \mathrm{a}$ \\
\hline $\mathrm{Zn}(\mathrm{ppm})$ & $119.08 \mathrm{a}$ & $113.75 \mathrm{a}$ & $108.58 \mathrm{a}$ & $116.75 \mathrm{a}$ & $114.00 \mathrm{a}$ \\
\hline $\mathrm{Cu}(\mathrm{ppm})$ & $24.83 \mathrm{a}$ & $21.75 \mathrm{a}$ & $20.58 \mathrm{a}$ & $22.17 \mathrm{a}$ & $20.83 \mathrm{a}$ \\
\hline
\end{tabular}

${ }^{\mathrm{z}}$ The means followed by the same letters are not significantly $(P \leq 0.05)$ different according to the Tukey-Kramer test.

absorption ability of biochar for ammonium (through cation exchange) and nitrate (in solution in biochar pores) (PrendergastMiller et al., 2014). According to Olmo et al. (2016), biochar addition reduced $\mathrm{N}$ availability but increased available $\mathrm{P}$ to plants. They expected that the $\mathrm{N}$ availability reduction also must have decreased the plant aboveground and belowground $\mathrm{N}$ concentrations. However, they only observed significant effects in wheat aboveground tissue, not in underground tissue. Decreased $\mathrm{N}$ content in the root but not in the plant aboveground part was observed during the current study.

Phosphorus has a major role in the growth of new tissues and cell division of plants (Vance et al., 2003). It is the main component of the nucleic acid structure, which is responsible for regulating the synthesis and stability of membranes in plant cells. Furthermore, $\mathrm{P}$ is a critical component of nucleic acid syn- thesis. The structures of both deoxyribonucleic acid and ribonucleic acid are linked by $\mathrm{P}$ (Huang et al., 2019). Third, plants perform complex energy transmissions that require $\mathrm{P}$ fertilization. Phosphorus is crucial for denosine-5' -triphosphate components. ATP exists in all plants from early growth to maturity and is essential for energy generation and carbohydrate metabolism (Bieleski and Ferguson, 1983).

During this experiment, interesting results were found regarding the absorption of $\mathrm{P}$ and $\mathrm{Mg}$, which are the only elements that are increased in soil, root, and leaf exposed to biochar treatment. Similarly, in a biochar experiment involving wheat root development, Olmo et al. (2016) reported that the application of biochar reduced $\mathrm{N}$ and $\mathrm{Mn}$ availability in soil but significantly increased the available concentration of P. However, the present study further indicated that soil amendment with biochar could affect the whole absorption pathway of P. At present, the global $\mathrm{P}$ demand for agricultural crop production is alleviated by a large amount of mineral $\mathrm{P}$ fertilizer that has more than $15,000,000 \mathrm{Mg}$ (Wang et al., 2012). Phosphorus in fertilizer is divided into two parts. Only $5 \%$ to $30 \%$ of $\mathrm{P}$ is eventually consumed by crops. The rest of $\mathrm{P}$ is fixed, complexed, precipitated, and leached into the soil, thereby making the plants unable to use it (Pierzynski et al., 2005). In tropical and subtropical areas, such as Florida, most soils are acidic because of high weathering rates and heavy rainfall. Acidic cations, such as aluminum ( $\mathrm{Al}$ ) and $\mathrm{Fe}$, are predominate in such soils, and they can fix a large amount of applied inorganic $\mathrm{P}$ depending on the soil $\mathrm{pH}$ (Adnan et al., 2003). It has been reported that biochar may improve $\mathrm{P}$ availability by minimizing $\mathrm{P}$ fixation in acid soils because of its high affinity to $\mathrm{Al}$ and $\mathrm{Fe}$ in soils (Chang et al., 2014). Their affinity enables the long- 


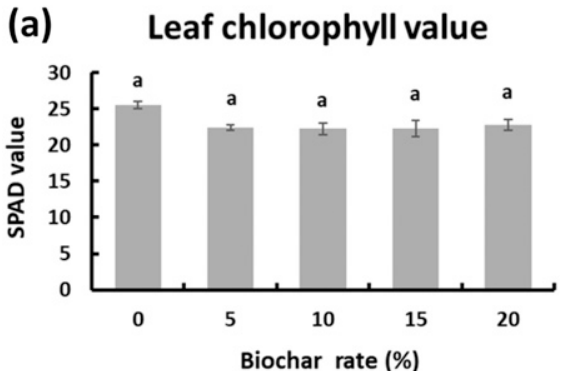

(b) Leaf chlorophyll value

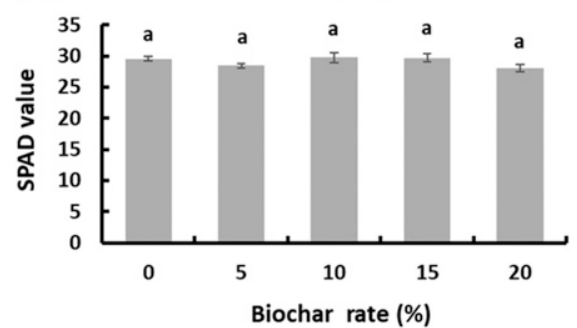

Fig. 4. Leaf chlorophyll [soil plant analysis development (SPAD) reading] values of the newest six mature leaves of muscadine grape at $(\mathbf{A})$ $35 \mathrm{~d}$ and (B) $54 \mathrm{~d}$ after transplanting. Bars with the same letters indicate that the means are not significantly $(P \leq 0.05)$ different according to the Tukey-Kramer test. Error bars show the SE $(\mathrm{n}=12)$.

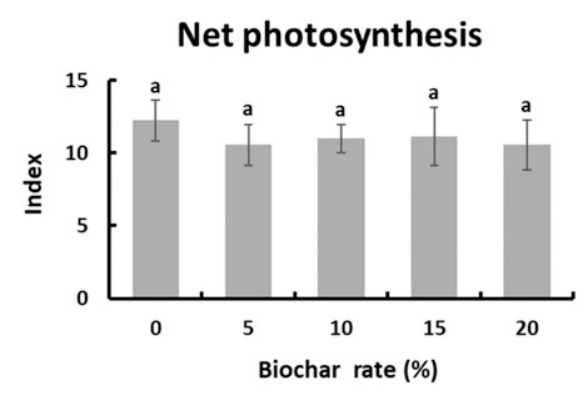

Fig. 5. Leaf photosynthesis net of muscadine grape plants measured 16 weeks after transplanting with the three newest mature leaves. Bars with the same letters indicate that the means are not significantly $(P \leq 0.05)$ different according to the Tukey-Kramer test. Error bars show the SE $(\mathrm{n}=12)$

term chelation of $\mathrm{Al}$ and $\mathrm{Fe}$ instead of $\mathrm{P}$. The mechanisms behind soil $\mathrm{P}$ availability with biochar treatment are not fundamentally understood (Mukherjee et al., 2019). It has also been speculated that soil amendment with biochar may affect the availability of soil $\mathrm{P}$ by regulating the activities of microbial enzymes in soil (Chen et al., 2011; Zhai et al., 2015).

Muscadine grape physiological performance. There was no significant difference in SPAD readings among the treatments (Fig. 4). Similarly, Quilliam et al. (2012) reported that biochar had no significant effect on SPAD measurements or plant height of dwarf bean during a 3-year field (a) Stem dry weight

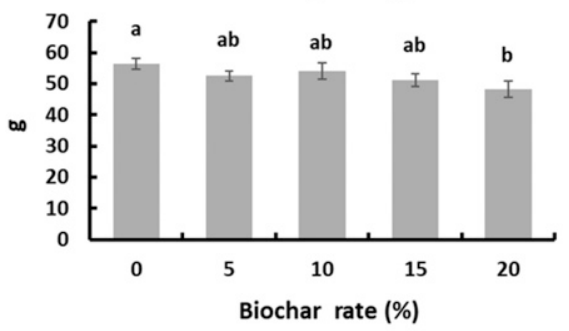

(b) Root dry weight

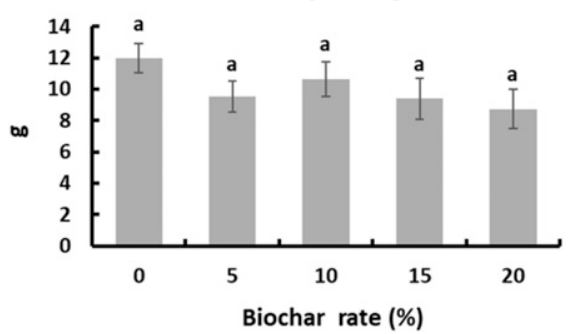

Fig. 6. (A) Shoot and (B) root dry weight of muscadine grapes determined after $72 \mathrm{~h}$ at $45{ }^{\circ} \mathrm{C}$ in a drying oven. Bars with the same letters indicate that the means are not significantly $(P \leq 0.05)$ different according to the Tukey-Kramer test. Error bars show the SE $(\mathrm{n}=$ 12).

experiment in the United Kingdom. However, another field experiment in northern Laos showed that the application of biochar reduced the SPAD value of rice leaves; it was reported that biochar application can potentially improve soil productivity of upland rice production in Laos, but the effect is highly dependent on fertilizer management (Asai et al., 2009).

The net photosynthesis data collected 16 weeks after transplantation are shown in Fig. 5. The results illustrated that pinewood biochar did not affect the leaf net photosynthesis in muscadine grape. Similarly, Xu et al. (2015) reported that peanut shell biochar application to an acidic ( $\mathrm{pH}$ 5.6) sandy loam soil with low contents of many mineral nutrients generally did not affect the photosynthesis of peanut leaves. Other studies also suggested no detectable differences in the physiological variables of leaves, such as photosynthesis, under various salinity and fertilization treatments (Alburquerque et al., 2013; Thomas et al., 2013). However, some other research showed the opposite results. Wang et al. (2014) found rice husk biochar applied to replant soil at $80 \mathrm{~g} \cdot \mathrm{kg}^{-1}$ can enhance plant height, fresh weight, and photosynthetic parameters (Wang et al., 2014). In addition, biochar application enhanced the in situ leaf photosynthetic rate of tomato and grape plants under drought stress (Akhtar et al., 2014). In contrast, Kammann et al. (2011) found that crop photosynthesis declined in quinoa on biochar-ameliorated soil when the soil moisture remained constant (Kammann et al., 2011).
Figure 6 shows that $20 \%$ biochar had a negative effect on the dry stem weight during the pot experiment. In general, there was no significant difference in the stem and root dry weights among treatments. Other studies confirmed no significant differences in the aboveground biomass and levels of foliar nutrients (Quilliam et al., 2012). In addition, Peng et al. (2016) found that soil amendment with biochar did not significantly improve the peanut yield and aboveground biomass, and they suggested that the application of organic manure was a more appropriate practice for hillslope Ultisols management than biochar. According to Abrishamkesh et al. (2015), the biochar type, interaction between biochar type, and biochar application rate had no significant effects on the aboveground and belowground biomass of lentils. Biochar application had no significant effect on the aboveground dry biomass, but it had a significant effect $(P<0.01)$ on the root dry biomass.

\section{Conclusion}

This is the first report of the effect of biochar application on muscadine grape growth. Soils in Citra, FL (Central Florida) are dominated by sandy soils, which have a naturally high leaching capacity and limited water-holding capacity. According to the results, biochar amendment had a strong impact on improving soil physical properties, explaining its positive effects on root traits. Pinewood biochar reduced soil temperature and soil bulk density and increased soil moisture, CEC, organic matter, and $\mathrm{pH}$. Another interesting result of this experiment was that pinewood biochar increased the nutrient contents of $\mathrm{P}, \mathrm{K}, \mathrm{Mg}$, and $\mathrm{Ca}$ in the soil. However, when the nutrients were transferred to plant root and leaf successively, a significant increase was only detected in the $\mathrm{P}$ content rather than the contents of other nutrient elements.

On the contrary, biochar did not affect leaf greenness, photosynthesis, or plant biomass. However, during this greenhouse experiment, our work focused on the influence of biochar application on muscadine grape growth during the early stage only. Further studies are needed to assess the long-term effects of biochar application on plant nutrient uptake and physiological performance, and especially on the nutrient absorption pathway and utilization efficiency.

\section{Literature Cited}

Aamer, M., M. Shaaban, M.U. Hassan, H. Guoqin, L. Ying, T.H. Ying, F. Rasul, M. Qiaoying, L. Zhuanling, and A. Rasheed. 2020. Biochar mitigates the $\mathrm{N} 2 \mathrm{O}$ emissions from acidic soil by increasing the nosZ and nirK gene abundance and soil pH. J. Environ. Manage. 255:109891, doi: 10.1016/j.jenvman.2019.109891.

Abrishamkesh, S., M. Gorji, H. Asadi, G. BagheriMarandi, and A. Pourbabaee. 2015. Effects of rice husk biochar application on the properties of alkaline soil and lentil growth. Plant Soil 
Environ. 61:475-482, doi: 10.17221/117/2015PSE.

Adnan, A., D.S. Mavinic, and F.A. Koch. 2003. Pilot-scale study of phosphorus recovery through struvite crystallization examining the process feasibility. J. Environ. Eng. Sci. 2:315324, doi: 10.1139/s03-040.

Agegnehu, G., A.M. Bass, P.N. Nelson, and M.I. Bird. 2016. Benefits of biochar, compost and biochar-compost for soil quality, maize yield and greenhouse gas emissions in a tropical agricultural soil. Sci. Total Environ. 543:295306, doi: 10.1016/j.scitotenv.2015.11.054.

Agegnehu, G., A.M. Bass, P.N. Nelson, B. Muirhead, G. Wright, and M.I. Bird. 2015. Biochar and biochar-compost as soil amendments: Effects on peanut yield, soil properties and greenhouse gas emissions in tropical North Queensland, Australia. Agr. Ecosyst. Environ. 213:72-85, doi: 10.1016/j.agee.2015.07.027.

Aggangan, N.S., A.D. Cortes, R.B. Opulencia, J.G. Jomao-as, and R.P. Yecyec. 2019. Effects of mycorrhizal fungi and bamboo biochar on the rhizosphere bacterial population and nutrient uptake of cacao (Theobroma cacao L.). Seedlings. Philipp. J. Crop Sci. (PJCS) 44:1-9.

Akhtar, S.S., G. Li, M.N. Andersen, and F. Liu. 2014. Biochar enhances yield and quality of tomato under reduced irrigation. Agr. Water Manage. 138:37-44, doi: 10.1016/j.agwat.2014.02.016.

Alburquerque, J.A., P. Salazar, V. Barron, J. Torrent, M.D. del Campillo, A. Gallardo, and R. Villar. 2013. Enhanced wheat yield by biochar addition under different mineral fertilization levels. Agron. Sustain. Dev. 33:475-484, doi: 10.1007/s13593-012-0128-3.

Ali, S., M. Rizwan, M.F. Qayyum, Y.S. Ok, M. Ibrahim, M. Riaz, M.S. Arif, F. Hafeez, M.I. Al-Wabel, and A.N. Shahzad. 2017. Biochar soil amendment on alleviation of drought and salt stress in plants: A critical review. Environ. Sci. Pollut. Res. 24:12700-12712, doi: 10.1007/s11356-017-8904-x.

Asai, H., B.K. Samson, H.M. Stephan, K. Songyikhangsuthor, K. Homma, Y. Kiyono, Y. Inoue, T. Shiraiwa, and T. Horie. 2009. Biochar amendment techniques for upland rice production in Northern Laos: 1. Soil physical properties, leaf SPAD and grain yield. Field Crops Res. 111:81-84, doi: 10.1016/j.fcr.2008. 10.008 .

Atkinson, C.J., J.D. Fitzgerald, and N.A. Hipps. 2010. Potential mechanisms for achieving agricultural benefits from biochar application to temperate soils: A review. Plant Soil 337:1-18, doi: 10.1007/s11104-010-0464-5.

Bailey, V.L., S.J. Fansler, J.L. Smith, and H. Bolton. 2011. Reconciling apparent variability in effects of biochar amendment on soil enzyme activities by assay optimization. Soil Biol. Biochem. 43:296-301, doi: 10.1016/ j.soilbio.2010.10.014.

Batista, E.M., J. Shultz, T.T. Matos, M.R. Fornari, T.M. Ferreira, B. Szpoganicz, R.A. de Freitas, and A.S. Mangrich. 2018. Effect of surface and porosity of biochar on water holding capacity aiming indirectly at preservation of the amazon biome. Sci. Rep. 8:10677, doi: 10.1038/s41598-018-28794-z.

Berek, A.K., N.V. Hue, T.J. Radovich, and A.A. Ahmad. 2018. Biochars improve nutrient phytoavailability of Hawai'i's highly weathered soils. Agronomy 8:203, doi: 10.3390/agronomy8100203.

Bieleski, R. and I. Ferguson. 1983. Physiology and metabolism of phosphate and its compounds, $\mathrm{p}$. 422-449. In: Inorganic plant nutrition. Springer, Berlin, Germany. doi: 10.1007/9783-642-68885-0_15.
Bigelow, C.A., D.C. Bowman, and D.K. Cassel. 2001. Nitrogen leaching in sand-based rootzones amended with inorganic soil amendments and sphagnum peat. J. Amer. Soc. Hort. Sci. 126:151-156, doi: 10.21273/ JASHS.126.1.151.

Bravo, S., J. Amorós, C. Pérez-De-Los-Reyes, F, García, M. Moreno, M. Sánchez-Ormeño, and P. Higueras. 2017. Influence of the soil $\mathrm{pH}$ in the uptake and bioaccumulation of heavy metals ( $\mathrm{Fe}, \mathrm{Zn}, \mathrm{Cu}, \mathrm{Pb}$ and $\mathrm{Mn}$ ) and other elements ( $\mathrm{Ca}, \mathrm{K}, \mathrm{Al}, \mathrm{Sr}$ and $\mathrm{Ba}$ ) in vine leaves, Castilla-La Mancha (Spain). J. Geochem. Explor. 174:79-83, doi: 10.1016/j.gexplo.2015.12.012.

Brown, S. P., D. Treadwell, J. Stephens, and S. Webb. 2018. Florida vegetable gardening guide. UF/IFAS Extension Service, University of Florida, IFAS, Florida A \& M University Cooperative Extension Program Publication SP 103.

Bruun, E.W., C.T. Petersen, E. Hansen, J.K. Holm, and H. Hauggaard-Nielsen. 2014. Biochar amendment to coarse sandy subsoil improves root growth and increases water retention. Soil Use Manage. 30:109-118, doi: 10.1111/ sum. 12102 .

Buss, W., C. Kammann, and H.W. Koyro. 2012. Biochar reduces copper toxicity in chenopodium quinoa willd. in a sandy soil. J. Environ. Qual. 41:1157-1165, doi: 10.2134/jeq2011.0022.

Buss, W., J.G. Shepherd, K.V. Heal, and O. Mašek. 2018. Spatial and temporal microscale $\mathrm{pH}$ change at the soil-biochar interface. Geoderma 331:50 52, doi: 10.1016/j.geoderma.2018.06.016.

Case, S.D.C., N.P. McNamara, D.S. Reay, and J. Whitaker. 2012. The effect of biochar addition on $\mathrm{N} 2 \mathrm{O}$ and $\mathrm{CO} 2$ emissions from a sandy loam soil - The role of soil aeration. Soil Biol. Biochem. 51:125-134, doi: 10.1016/j.soilbio.2012.03.017.

Chen, B., Z. Chen, and S. Lv. 2011. A novel magnetic biochar efficiently sorbs organic pollutants and phosphate. Bioresour. Technol. 102:716-723, doi: 10.1016/j.biortech.2010.08.067.

Chang, H.Y., O.H. Ahmed, and N.M.A. Majid. 2014. Improving phosphorus availability in an acid soil using organic amendments produced from agroindustrial wastes. ScientificWorldJournal, doi: 10.1155/2014/506356.

Clough, T., L. Condron, C. Kammann, and C. Müller. 2013. A review of biochar and soil nitrogen dynamics. Agronomy 3:275-293, doi: 10.3390/agronomy3020275.

Collins, M.E. 2017. Soils of Florida and the Caribbean: LRRs U and Z, p. 281-303. In: The soils of the USA. Springer, Berlin, Germany.

Compant, S., C. Clement, and A. Sessitsch. 2010. Plant growth-promoting bacteria in the rhizoand endosphere of plants: Their role, colonization, mechanisms involved and prospects for utilization. Soil Biol. Biochem. 42:669-678, doi: 10.1016/j.soilbio.2009.11.024.

Dempster, D.N., D.B. Gleeson, Z.M. Solaiman, D.L. Jones, and D.V. Murphy. 2012. Decreased soil microbial biomass and nitrogen mineralisation with Eucalyptus biochar addition to a coarse textured soil. Plant Soil 354:311-324, doi: 10.1007/s11104-011-1067-5.

Duan, Y., S.K. Awasthi, T. Liu, H. Chen, Z. Zhang, Q. Wang, X. Ren, Z. Tu, M.K. Awasthi, and M.J. Taherzadeh. 2019. Dynamics of fungal diversity and interactions with environmental elements in response to wheat straw biochar amended poultry manure composting. Bioresour. Technol. 274:410-417, doi: 10.1016/ j.biortech.2018.12.020.

Duarte Alonso, A. and M.A. O'Neill. 2012. Consumption of muscadine grape by-products: An exploration among Southern US consumers. Brit. Food J. 114:400-415, doi: 10.1108/ 00070701211213492.

El-Dine, T.G. and M.M. Hosny. 2000. Field evaluation of surge and continuous flows in furrow irrigation systems. Water Resources Manag. 14:77-87, doi: 10.1023/A:1008189004992.

Ferreira, C., F. Verheijen, J. Puga, J. Keizer, and A. Ferreira. 2017. Biochar in vineyards: Impact on soil quality and crop yield four years after the application, p. 1600. EGU General Assembly Conf. (abstr.).

Gao, S., K. Hoffman-Krull, A. Bidwell, and T. DeLuca. 2016. Locally produced wood biochar increases nutrient retention and availability in agricultural soils of the San Juan Islands, USA. Agr. Ecosyst. Environ. 233:43-54, doi: 10.1016/j.agee.2016.08.028.

Gaspar, A.P. and C.A. Laboski. 2016. Base saturation: What is it? Should I be concerned? Does it affect my fertility program, p. 55-61. In: Proc. 2016 Wis. Crop Manage. Conf.

Genesio, L., F. Miglietta, S. Baronti, and F.P. Vaccari. 2015. Biochar increases vineyard productivity without affecting grape quality: Results from a four years field experiment in Tuscany. Agr. Ecosyst. Environ. 201:20-25, doi: 10.1016/j.agee.2014.11.021.

Gillette, D.A. and T.R. Walker. 1977. Characteristics of airborne particles produced by wind erosion of sandy soil, high plains of west Texas. Soil Sci. 123:97-110.

Githinji, L. 2014. Effect of biochar application rate on soil physical and hydraulic properties of a sandy loam. Arch. Agron. Soil Sci. 60:457470, doi: 10.1080/03650340.2013.821698.

Glaser, B., J. Lehmann, and W. Zech. 2002. Ameliorating physical and chemical properties of highly weathered soils in the tropics with charcoal - a review. Biol. Fertil. Soils 35:219-230, doi: 10.1007/s00374-002-0466-4.

Gondek, K., M. Mierzwa-Hersztek, M. Kopeć, J. Sikora, T. Głąb, and K. Szczurowska. 2019. Influence of biochar application on reduced acidification of sandy soil, increased cation exchange capacity, and the content of available forms of $\mathrm{K}, \mathrm{Mg}$, and P. Pol. J. Environ. Stud. 28:103-111, doi: 10.15244/pjoes/81688.

Huang, J., Z. Huang, X. Zhou, C. Xia, M. Imran, S. Wang, C. Xu, M. Zha, Y. Liu, and C. Zhang. 2019. Tissue-specific transcriptomic profiling of Plantago major provides insights for the involvement of vasculature in phosphate deficiency responses. Mol. Genet. Genomics 294:159175, doi: 10.1007/s00438-018-1496-4.

Ippolito, J.A., D.A. Laird, and W.J. Busscher. 2012. Environmental Benefits of Biochar. J. Environ. Qual. 41:967-972, doi: 10.2134/ jeq2012.0151.

Irfan, M., Q. Hussain, K.S. Khan, M. Akmal, S.S. Ijaz, R. Hayat, A. Khalid, M. Azeem, and M. Rashid. 2019. Response of soil microbial biomass and enzymatic activity to biochar amendment in the organic carbon deficient arid soil: A 2-year field study. Arab. J. Geosci. 12:95, doi: 10.1007/s12517-019-4239-x.

Isaac, R.A. and W.C. Johnson. 1985. Elemental analysis of plant tissue by plasma emission spectroscopy: Collaborative study. J. Assoc. Off. Anal. Chem. 68:499-505, doi: 10.1093/ jaoac/68.3.499.

Jeffery, S., D. Abalos, M. Prodana, A.C. Bastos, J.W. Van Groenigen, B.A. Hungate, and F. Verheijen. 2017. Biochar boosts tropical but not temperate crop yields. Environ. Res. Lett. 12:053001, doi: 10.1088/1748-9326/aa67bd.

Kammann, C., S. Ratering, C. Eckhard, and C. Muller. 2012. Biochar and hydrochar effects 
on greenhouse gas (carbon dioxide, nitrous oxide, and methane) fluxes from soils. J. Environ. Qual. 41:1052-1066, doi: 10.2134/ jeq2011.0132.

Kammann, C.I., S. Linsel, J.W. Gößling, and H.-W. Koyro. 2011. Influence of biochar on drought tolerance of Chenopodium quinoa Willd and on soil-plant relations. Plant Soil 345:195-210, doi: 10.1007/s1 1104-011-0771-5.

Kan, T., V. Strezov, and T.J. Evans. 2016. Lignocellulosic biomass pyrolysis: A review of product properties and effects of pyrolysis parameters. Renew. Sustain. Energy Rev. 57:1126-1140, doi: 10.1016/j.rser.2015.12.185.

Kaurin, A., Z. Cernilogar, and D. Lestan. 2018. Revitalisation of metal-contaminated, EDTAwashed soil by addition of unpolluted soil, compost and biochar: Effects on soil enzyme activity, microbial community composition and abundance. Chemosphere 193:726-736, doi: 10.1016/j.chemosphere.2017.11.082.

Laghari, M., M.S. Mirjat, Z. Hu, S. Fazal, B. Xiao, M. $\mathrm{Hu}, \mathrm{Z}$. Chen, and D. Guo. 2015. Effects of biochar application rate on sandy desert soil properties and sorghum growth. Catena 135:313-320, doi: 10.1016/j.catena.2015.08.013.

Laird, D.A. 2008. The charcoal vision: A win-winwin scenario for simultaneously producing bioenergy, permanently sequestering carbon, while improving soil and water quality. Agron. J. 100:178-181, doi: 10.2134/agronj2007.0161.

Lehmann, J. and S. Joseph. 2015. Biochar for environmental management: Science, technology and implementation. Routledge, London, UK.

Lehmann, J., M.C. Rillig, J. Thies, C.A. Masiello, W.C. Hockaday, and D. Crowley. 2011. Biochar effects on soil biota - A review. Soil Biol. Biochem. 43:1812-1836, doi: 10.1016/j.soilbio.2011.04.022

Liu, Z., B. Dugan, C.A. Masiello, R.T. Barnes, M.E. Gallagher, and H. Gonnermann. 2016. Impacts of biochar concentration and particle size on hydraulic conductivity and DOC leaching of biochar-sand mixtures. J. Hydrol. 533:461472, doi: 10.1016/j.jhydrol.2015.12.007.

Major, J., M. Rondon, D. Molina, S.J. Riha, and J. Lehmann. 2010. Maize yield and nutrition during 4 years after biochar application to a Colombian savanna oxisol. Plant Soil 333:117128, doi: 10.1007/s11104-010-0327-0.

Marchi, E.C., L. Zotarelli, J.A. Delgado, D.L. Rowland, and G. Marchi. 2016. Use of the Nitrogen Index to assess nitrate leaching and water drainage from plastic-mulched horticultural cropping systems of Florida. Intl. Soil Water Conserv. Res. 4:237-244, doi: 10.1016/ j.iswer.2016.12.001.

Marshall, J., R. Muhlack, B.J. Morton, L. Dunnigan, D. Chittleborough, and C.W. Kwong. 2019. Pyrolysis temperature effects on biochar-Water interactions and application for improved water holding capacity in vineyard soils. Soil Syst. 3:27, doi: 10.3390/soilsystems3020027.

Marx, E., J. M. Hart, and R. G. Stevens. 1996. Soil test interpretation guide. Oregon State University Extension Service, Corvallis, OR.

Mohamed, B.A., N. Ellis, C.S. Kim, X. Bi, and A.E.-r. Emam. 2016. Engineered biochar from microwave-assisted catalytic pyrolysis of switchgrass for increasing water-holding capacity and fertility of sandy soil. Sci. Total Environ. 566:387-397, doi: 10.1016/j.scitotenv. 2016.04.169.

Mukherjee, S., M. Mavi, and J. Singh. 2019. Differential response of biochar derived from rice-residue waste on phosphorus availability in soils with dissimilar pH. Intl. J. Environ. Sci.
Technol. 17:3065-3074, doi: 10.1007/s13762019-02575-1.

Nikravesh, I., S. Boroomandnasab, and A.S.M. Abd Ali Naseri. 2019. Wheat straw biochar application to loam-sand soil: impact on yield components of summer maize and some soil properties. WORLD 8:54-60.

Novak, J., G. Sigua, D. Watts, K. Cantrell, P. Shumaker, A. Szogi, M.G. Johnson, and K. Spokas. 2016. Biochars impact on water infiltration and water quality through a compacted subsoil layer. Chemosphere 142:160-167, doi: 10.1016/j.chemosphere.2015.06.038.

Obia, A., J. Mulder, S.E. Hale, N.L. Nurida, and G. Cornelissen. 2018. The potential of biochar in improving drainage, aeration and maize yields in heavy clay soils. PLoS One 13:e0196794, doi: 10.1371/journal.pone.0196794.

Obour, P.B., E.O. Danso, A. Yakubu, S. AbenneyMickson, E.B. Sabi, Y.K. Darrah, and E. Arthur. 2019. Water retention, air exchange and pore structure characteristics after three years of rice straw biochar application to an Acrisol. Soil Sci. Soc. Amer. J. 83:16641671, doi: 10.2136/sssaj2019.07.0230.

Ohsowski, B.M., K. Dunfield, J.N. Klironomos, and M.M. Hart. 2018. Plant response to biochar, compost, and mycorrhizal fungal amendments in post-mine sandpits. Restor. Ecol. 26:63-72, doi: 10.1111/rec.12528.

Olmo, M., R. Villar, P. Salazar, and J.A. Alburquerque. 2016. Changes in soil nutrient availability explain biochar's impact on wheat root development. Plant Soil 399:333-343, doi: 10.1007/ s11104-015-2700-5.

Palansooriya, K.N., J.T.F. Wong, Y. Hashimoto, L. Huang, J. Rinklebe, S.X. Chang, N. Bolan, H. Wang, and Y.S. Ok. 2019. Response of microbial communities to biochar-amended soils: A critical review. Biochar 1:3-22, doi: 10.1007/ s42773-019-00009-2.

Paneque, M., M. José, J.D. Franco-Navarro, J.M. Colmenero-Flores, and H. Knicker. 2016. Effect of biochar amendment on morphology, productivity and water relations of sunflower plants under non-irrigation conditions. Catena 147:280 287, doi: 10.1016/j.catena.2016.07.037.

Peng, X., Q. Zhu, Z. Xie, F. Darboux, and N.M. Holden. 2016. The impact of manure, straw and biochar amendments on aggregation and erosion in a hillslope Ultisol. Catena 138:30-37, doi: 10.1016/j.catena.2015.11.008.

Petri, A.N. and A.M. Petrovic. 2001. Cation exchange capacity impacts on shoot growth and nutrient recovery in sand based creeping bentgrass greens. Intl. Turfgrass Soc. Res. J. 9:422427 .

Pierzynski, G.M., R.W. McDowell, and J. Thomas Sims. 2005. Chemistry, cycling, and potential movement of inorganic phosphorus in soils, p. 51-86. In: Phosphorus: Agriculture and the environment. Madison, WI. doi: 10.2134/agronmonogr46.c3.

Prendergast-Miller, M.T., M. Duvall, and S.P. Sohi. 2014. Biochar-root interactions are mediated by biochar nutrient content and impacts on soil nutrient availability. Eur. J. Soil Sci. 65:173185, doi: 10.1111/ejss.12079.

Quilliam, R.S., K.A. Marsden, C. Gertler, J. Rousk, T.H. DeLuca, and D.L. Jones. 2012. Nutrient dynamics, microbial growth and weed emergence in biochar amended soil are influenced by time since application and reapplication rate. Agr. Ecosyst. Environ. 158:192-199, doi: 10.1016/j.agee.2012.06.011.

Rees, F., M.O. Simonnot, and J.L. Morel. 2014. Short-term effects of biochar on soil heavy metal mobility are controlled by intra-particle diffusion and soil pH increase. Eur. J. Soil Sci. 65:149-161, doi: 10.1111/ejss.12107.

Reichert, J.M., T.J.C. Amado, D.J. Reinert, M.F. Rodrigues, and L.E.A.S. Suzuki. 2016. Land use effects on subtropical, sandy soil under sandyzation/desertification processes. Agr. Ecosyst. Environ. 233:370-380, doi: 10.1016/ j.agee.2016.09.039.

Rondon, M.A., J. Lehmann, J. Ramirez, and M. Hurtado. 2007. Biological nitrogen fixation by common beans (Phaseolus vulgaris L.) increases with bio-char additions. Biol. Fertil. Soils 43:699-708, doi: 10.1007/s00374-0060152-z.

Schwartz, M.W., J.D. Hoeksema, C.A. Gehring, N.C. Johnson, J.N. Klironomos, L.K. Abbott, and A. Pringle. 2006. The promise and the potential consequences of the global transport of mycorrhizal fungal inoculum. Ecol. Lett. 9:501-515, doi: 10.1111/j.1461-0248.2006.00910.x.

Silva, L.G., C.A. de Andrade, and W. Bettiol. 2020. Biochar amendment increases soil microbial biomass and plant growth and suppresses Fusarium wilt in tomato. Trop. Plant Pathol. 45:7383, doi: 10.1007/s40858-020-00332-1.

Sorrenti, G., M. Ventura, and M. Toselli. 2016. Effect of biochar on nutrient retention and nectarine tree performance: A three-year field trial. J. Plant Nutr. Soil Sci. 179:336-346, doi: 10.1002/jpln.201500497.

Thomas, S.C., S. Frye, N. Gale, M. Garmon, R. Launchbury, N. Machado, S. Melamed, J. Murray, A. Petroff, and C. Winsborough. 2013. Biochar mitigates negative effects of salt additions on two herbaceous plant species. J. Environ. Manage. 129:62-68, doi: 10.1016/ j.jenvman.2013.05.057.

Vaccari, F.P., S. Baronti, E. Lugato, L. Genesio, S. Castaldi, F. Fornasier, and F. Miglietta. 2011. Biochar as a strategy to sequester carbon and increase yield in durum wheat. Eur. J. Agron. 34:231-238, doi: 10.1016/j.eja.2011.01.006.

Vance, C.P., C. Uhde-Stone, and D.L. Allan. 2003. Phosphorus acquisition and use: Critical adaptations by plants for securing a nonrenewable resource. New Phytol. 157:423-447, doi: 10.1046/j.1469-8137.2003.00695.x.

Ventura, M., G. Sorrenti, P. Panzacchi, E. George, and G. Tonon. 2013. Biochar reduces shortterm nitrate leaching from a horizon in an apple orchard. J. Environ. Qual. 42:76-82, doi: 10.2134/jeq2012.0250.

Wang, T., M. Camps-Arbestain, M. Hedley, and P. Bishop. 2012. Predicting phosphorus bioavailability from high-ash biochars. Plant Soil 357:173-187, doi: 10.1007/s11104-012-1131-9.

Wang, Y., F. Pan, G. Wang, G. Zhang, Y. Wang, X. Chen, and Z. Mao. 2014. Effects of biochar on photosynthesis and antioxidative system of Malus hupehensis Rehd. seedlings under replant conditions. Scientia Hort. 175:9-15, doi: 10.1016/j.scienta.2014.05.029.

Wang, Z., C. Tang, H. Wang, C. Zhao, D. Yin, Y. Yuan, K. Yang, and Z. Li. 2019. Effect of different amounts of biochar on meadow soil characteristics and maize yields over three years. BioResources 14:4194-4209.

Weber, K. and P. Quicker. 2018. Properties of biochar. Fuel 217:240-261, doi: 10.1016/ j.fuel.2017.12.054.

Xu, C.-Y., S. Hosseini-Bai, Y. Hao, R.C. Rachaputi, H. Wang, Z. Xu, and H. Wallace. 2015. Effect of biochar amendment on yield and photosynthesis of peanut on two types of soils. Environ. Sci. Pollut. Res. Intl. 22:6112-6125, doi: 10.1007/ s11356-014-3820-9.

Yang, L., F. Liao, M. Huang, L. Yang, and Y. Li. 2015. Biochar improves sugarcane seedling 
root and soil properties under a pot experiment. Sugar Tech 17:36-40, doi: 10.1007/s12355014-0335-0.

Yu, O.-Y., B. Raichle, and S. Sink. 2013. Impact of biochar on the water holding capacity of loamy sand soil. Intl. J. Energy Environ. Eng. 4:44, doi: 10.1186/2251-6832-4-44.

Zhai, L., Z. CaiJi, J. Liu, H. Wang, T. Ren, X. Gai, B. Xi, and H. Liu. 2015. Short-term effects of maize residue biochar on phosphorus availability in two soils with different phosphorus sorption capacities. Biol. Fertil. Soils 51:113 122, doi: 10.1007/s00374-014-0954-3.
Zhang, A.F., Y.M. Liu, G.X. Pan, Q. Hussain, L.Q Li, J.W. Zheng, and X.H. Zhang. 2012a. Effect of biochar amendment on maize yield and greenhouse gas emissions from a soil organic carbon poor calcareous loamy soil from Central China Plain. Plant Soil 351:263-275, doi: 10.1007/s11104-011-0957-x.

Zhang, A.F., R.J. Bian, G.X. Pan, L.Q. Cui, Q. Hussain, L.Q. Li, J.W. Zheng, J.F. Zheng, X.H. Zhang, X.J. Han, and X.Y. Yu. 2012b. Effects of biochar amendment on soil quality, crop yield and greenhouse gas emission in a Chinese rice paddy: A field study of 2 consecutive rice growing cycles. Field Crops Res. 127:153-160, doi: 10.1016/j.fcr.2011.11.020.

Zhang, Q., Y. Wang, Y. Wu, X. Wang, Z. Du, X. Liu, and J. Song. 2013. Effects of biochar amendment on soil thermal conductivity, reflectance, and temperature. Soil Sci. Soc. Amer. J. 77:1478-1487, doi: 10.2136/ sssaj2012.0180.

Zhu, X., B. Chen, L. Zhu, and B. Xing. 2017. Effects and mechanisms of biochar-microbe interactions in soil improvement and pollution remediation: A review. Environ. Pollut. 227:98-115, doi: 10.1016/j.envpol.2017.04.032. 